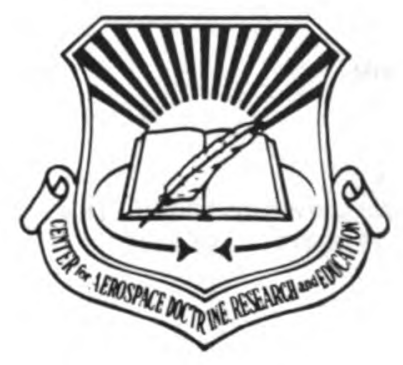

\title{
The Evolution of the Cruise Missile
}

by

KENNETH P. WERRELL

Air University ( $\mathrm{AU}$ )

Air University Press

Maxwell Air Force Base. Alabama

September 1985 